\title{
The art of omission: BRIM Nockberge - designing a Biosphere Reserve Integrated Monitoring for the Carinthian part of the Biosphere Reserve Salzburger Lungau \& Kärntner Nock- berge
}

\author{
Michael Jungmeier, Tobias Köstl, Sigrun Lange \& Markus Bliem
}

Keywords: biosphere reserves, integrated monitoring, UNESCO, protected area management

\section{Abstract}

This article provides an overview on BRIM Nockberge, a research project dedicated to the development of an integrated monitoring system aimed at displaying the performance of the Carinthian part of the newly established Biosphere Reserve (BR) Salzburger Lungau \& Kärntner Nockberge. Special emphasis has been placed on compactness and slenderness in this approach. Twelve indicators have been identified that are best suited to represent the social, economic and ecological development of the region, as well as the management's performance. The whole process of developing indicators has been implemented in close collaboration and communication with local stakeholders and experts to achieve maximum public acceptance and effectiveness of the monitoring approach.

A specific online database has been designed to store the collected data. It allows an easy and stringent presentation of the results. A test run was carried out within the project. Over the years, the annual collection of data will allow detecting relevant trends in the region.

\section{Profile}

Protected area

Salzburger Lungau \& Kärntner Nockberge Biosphere Reserve

Mountain range

Alps

Country

Austria

\section{Introduction}

According to Goldsmith (1991), monitoring is to detect change. It is a process of repeated collection and interpretation of relevant data. Disregarding the pioneer work in a few parks, such as the Swiss National Park, where scientific monitoring can be considered a constituent element of the park's history and identity (Kupper 2012), monitoring in the context of park management did not become relevant before the 1970s. At that time, international conventions (in particular the World Heritage Convention, the Ramsar Convention and the Convention on Biological Diversity with its Programme of Work on Protected Areas) and institutions such as the European Council started to request regular reports on the performance of their sites. More and more sophisticated monitoring schemes have been developed since then (cf. ALPARC 2011; Buer et al. 2013; Fancy et al. 2007; Kowatsch et al. 2011; Nolte et al. 2010; Stoll-Kleemann et al. 2012). However, due to a lack of resources their application still remains a challenge in practice. Extensive assessments, as required for instance in Article 17 of Europe's Habitats Directive from 1992, can surely be considered culmination points of monitoring requirements (Ellmauer 2005).

Since BRs derive from UNESCO's Man and the Biosphere Programme (1970), they have been encouraged right from the start to host globally relevant research for the surveillance of environmental changes. Thus monitoring has always been an important component of the logistic function of BRs (Lange 2005). In 1995, the Seville Strategy, re-launching BRs as model regions
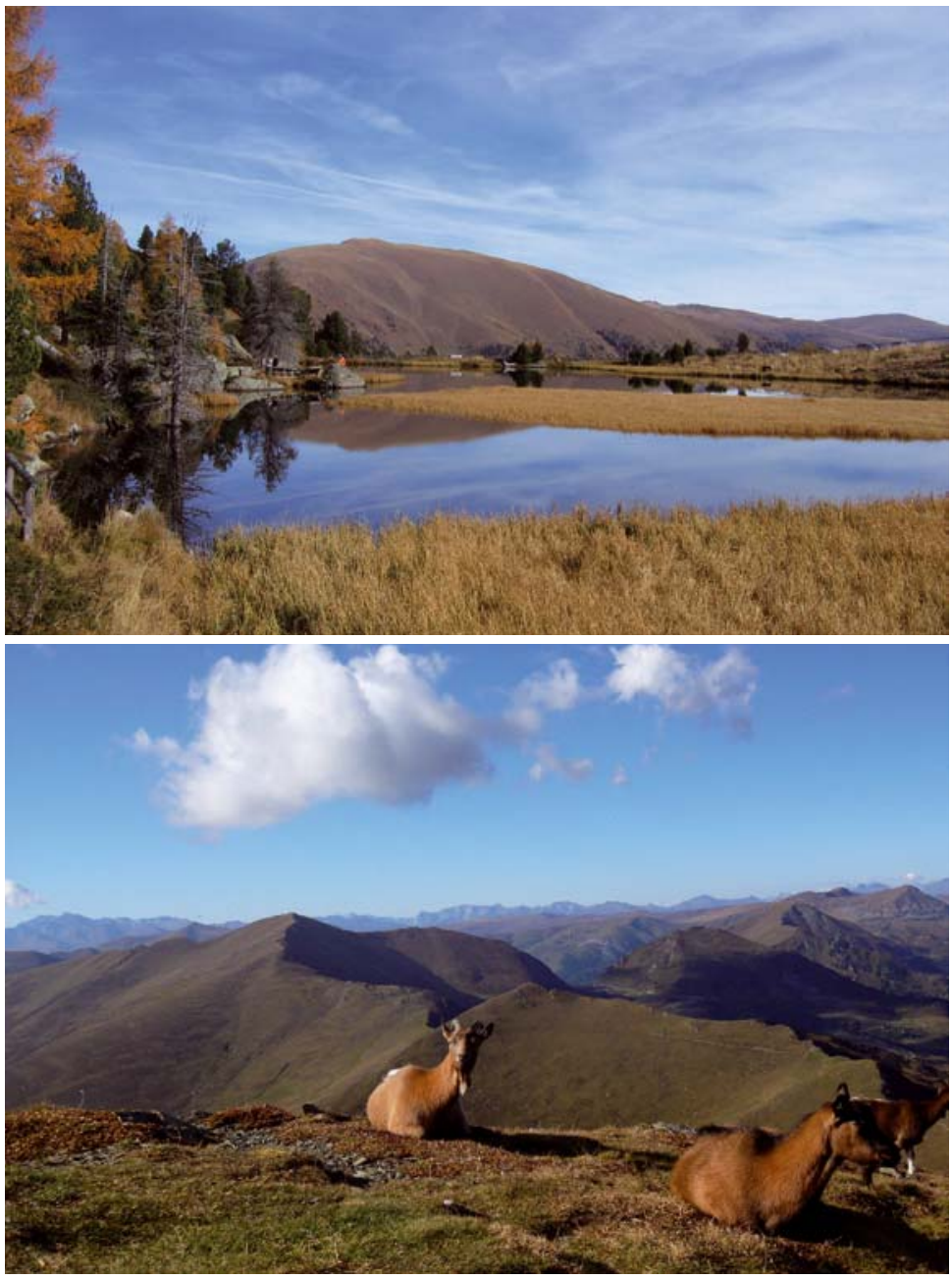

Figure 1 - Top: Towards a sustainable economic future? Bottom: A typical view in the Nockberge region. (C) E.C.O. Austria 


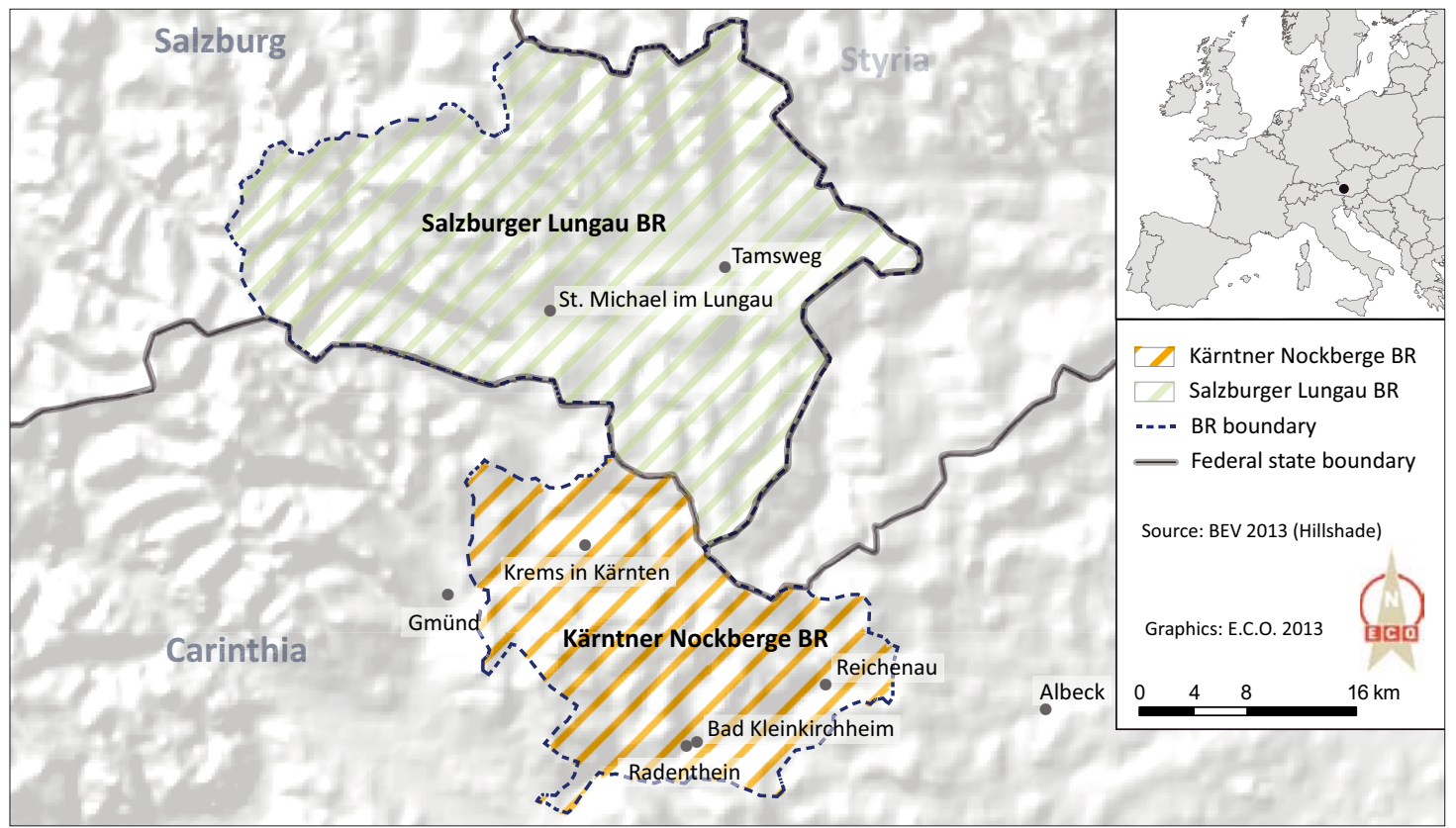

Figure 2 - Geographic location of Salžburger Lungau \& Kärntner Nockberge Biosphere Reserve (BR).

for sustainable development, re-emphasized the importance of a systematic monitoring scheme and periodic reviews. Step by step this has been put in place in many BRs across the world (e. g. Heinze 2004). In Austria, Fischer-Kowalski et al. (2008) conceptualized an integrated monitoring approach for BRs. The experts argued that due to the manifold functions of BRs, a great range of variables has to be covered - in the natural as well as in the social and economic spheres. However, experiences from practice show that for a monitoring tool to be applied successfully long-term it is crucial to avoid high costs and labour input.

\section{The study area and its particular require- ments}

After an exhausting participatory planning process of almost one decade (Jungmeier et al. 2009), the Biosphere Reserve Salzburger Lungau \& Kärntner Nockberge was recognized by the UNESCO in July 2012. Covering some 149599 hectares in two federal states, it is the largest BR in the Eastern Alps. It encompasses a mosaic of ecological systems, representative for the Alpine region. The BR is separately administrated by two entities, the management team of former Nockberge National Park (Carinthia), and the team of the regional association of Lungau (Salzburg). Both entities have signed a cooperation agreement to attune common aims and strategies.

Prior to its designation, it was claimed by stakeholders in the former Nockberge National Park, and promised by decision-makers in Carinthia, that an integrated monitoring scheme should already be in place before the BR would be launched. The idea was simply to have a number of key figures to measure the success of the park management. According to the regional discussion, the monitoring system should be very slim and easy to understand, with cost-efficiency another major issue. The expenditures for the monitoring should not exceed the costs of the annual financial statement of the park's administration. Given these requirements, an integrated monitoring scheme, the BRIM ${ }^{\text {Nockberge, }}$ was developed as a pilot study for the Carinthian part of the BR. Based on the findings and experiences from this study, the present monitoring approach is going to be extended to the Lungau part of the BR.

The project was financially supported by the Austrian Man and the Biosphere programme.

\section{Research question}

The study focused on the following research question: which simple set of indicators is appropriate to cover the various functions of a BR while being resource and cost efficient, and accepted by the relevant local stakeholder groups?

\section{Methods}

In the context of the research project, the surveyed indicators have been assigned to four dimensions: the ecological, the economic, the socio-cultural, and the management dimension. These dimensions are related to the three basic functions of BRs. The indicators of the ecological dimension relate to the conservation function of the BR; those of the economic and social dimensions reflect the development function; the indicators subsumed under the management performance are indicating efforts related to the logistic function for research, monitoring and educational activities. In a first step, more than one hundred indicators have been pre-selected from existing monitoring approaches and literature. Subsequently, each indicator had to comply with the following criteria: relevance, availabil- 
ity, sensitivity and consistency. For each of the four dimensions, three indicators have been identified, which are illustrated in Table 1. After intensive discussions and consultative processes with experts and local decision-makers (represented in the former National Park Committee, now BR Committee) over a period of ten months, some minor adaptations were made. This process is shown in the following scheme (Figure 3).

Generally, an indicator is considered to be relevant if it is related to the agreed management objectives of the BR in question. However, in case of the young Kärntner Nockberge BR a management plan does not yet exist. In accordance with the national criteria for Austrian BRs, a management plan has to be developed within a period of three years from its designation. As the monitoring tool should be available before the $\mathrm{BR}$ is recognized, the indicators have been related to the management objectives indicated by the staff and the BR Committee, the decision-making body of the park. Generally the significance of the results is expected to increase in proportion to the regularity of the data collection. The Carinthian management of the BR will collect data once a year. In order to buffer irregularities, all figures are being calculated as rolling mean values of the annual figures for the last five years (Figure 4). This means that the performance of the last year is subtracted from the performance of the current year and related to the mean value of the last five years, excluding the current year. Nevertheless, the isolated annual data are also to be considered in the interpretation process to avoid an essential loss of information.

The analysis of the monitoring results is one of the critical issues. A specific online-database has been designed to store the collected data. It allows for an easy interpretation of the collected data and the assessment of relevant trends in the development of the BR. Subsequently, the processed data have to be interpreted with regard to the management objectives and thus can be used for adapting and improving management performance.

Once the indicators had been selected and the database installed, a first test-run was carried out. The data of some indicators were compared with data from a neighbouring region outside the BR. Equivalent to the four communities forming the Carinthian part of the BR (Bad Kleinkirchheim, Krems in Carinthia, Radenthein and Reichenau), four reference communities were selected (Albeck, Friesach, Gloednitz, Metnitz). They are comparable in geomorphology, size and number of inhabitants but differ with respect to the conservation status and the touristic value. This comparative approach has been applied whenever the monetary and labour costs stayed within reasonable limits.

\section{Results}

In the course of the project, three different results have been achieved:

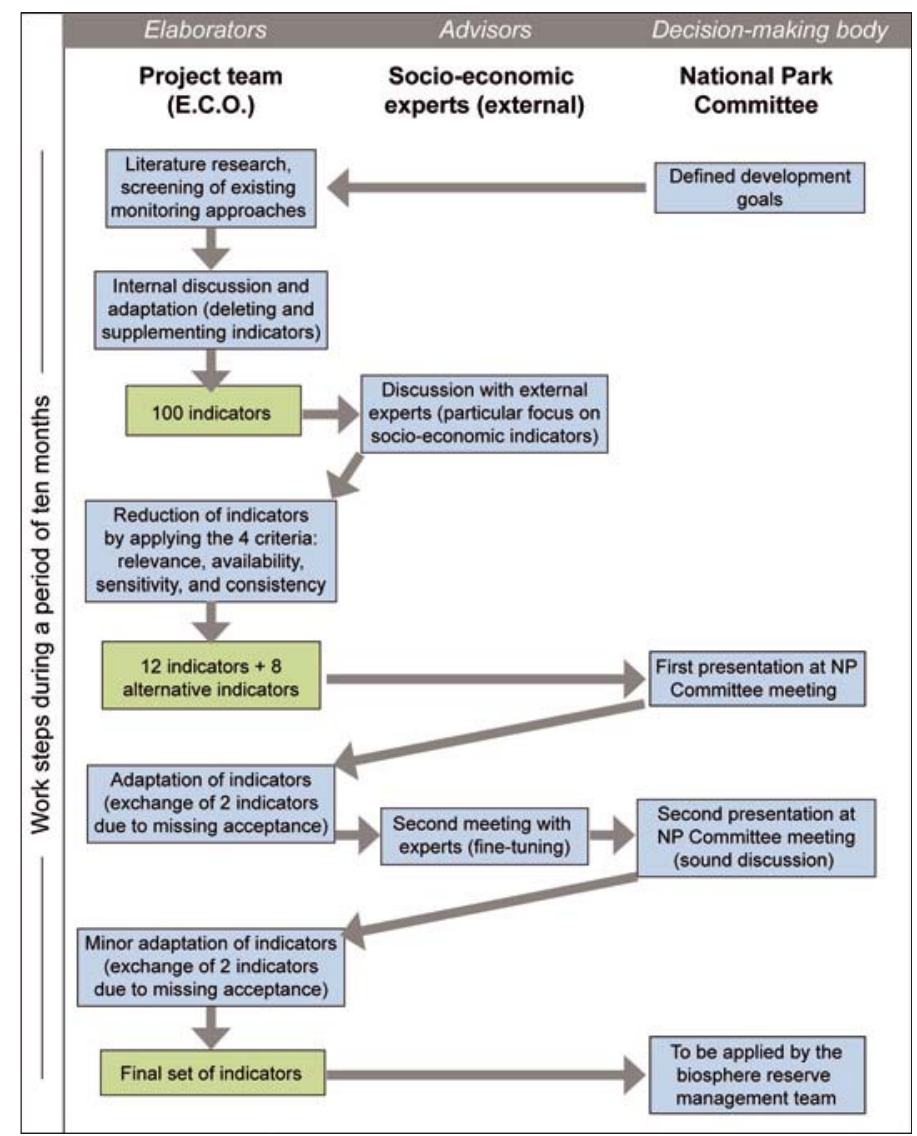

Figure 3 - Scheme showing the process of identifying the indicators. The $\mathrm{Na}$ tional Park Committee has been transformed into the BR Committee. Chart created by the authors.

\begin{tabular}{|c|c|}
\hline \multicolumn{2}{|c|}{ (performance of the current year) - (performance of the last year) } \\
\hline \multicolumn{2}{|c|}{ mean value of the last five years, excluding the current year } \\
\hline$P_{r e l}=\frac{P_{n+1}-P_{n}}{\sum_{j=1}^{n} P_{j}}, \mathrm{j}<\mathrm{n}$ & $\begin{array}{lll}P_{\text {rel }} & \ldots & \text { relative "performance" } \\
P_{n+1} \ldots & \text { indicator of the actual year } \\
P_{n}^{n} \ldots & \text { indicator of the previous year } \\
n & \ldots & \text { number of values (five) }\end{array}$ \\
\hline$n$ & \\
\hline
\end{tabular}

Figure 4 - Calculation of relative performance by rolling mean values. Chart created by the authors.

- development of a set of twelve indicators, appropriate to monitor the performance of the Carinthian part of the BR;

- development of an online database to systematically store and interpret the collected data;

implementation of a test-run of the monitoring system (partly also implemented in the reference region).

\section{Set of indicators}

As a result of the participatory process, a set of twelve indicators has been chosen to assess the performance of the BR. Several indicators seemed to be appropriate but finally had to be dropped in the course of the discussions with the BR Committee. Either they did not meet the criteria of being relevant, avail- 
able, sensitive and consistent, or they were refused by specific stakeholder groups. The indicator gender mainstreaming (which means equal opportunities for everybody), for example, was suggested to be included in the monitoring scheme as it is considered to be very important for social justice, a key issue of sustainable development. However, this indicator was dropped as it was considered to be too difficult to assess.

The present choice of indicators constitutes the basic set of the monitoring tool (Table 1). The management body will carry out additional thematic analyses, the screenshots, which allow a more thorough examination of specific issues, such as gender equity, dissemination of best practice with respect to sustainable land use, or education. In this way, specific issues can be covered which are not currently represented by the set of indicators. By analysis on short-term demand the management is able to react very quickly to upcoming questions and requirements.

Below the selected indicators and the reasoning behind them are briefly outlined.

Indicators representing the ecological dimension:

The population development of Nigritella rhellicani, an Alpine orchid species sensitive to intensive grazing, is being monitored by yearly counting of individuals on fixed plots. Five of these plots are located in each of the core areas and in the buffer zones of the BR. The sampling plots have been allocated randomly at elevations of 1900 metres and beyond. In the long run, a balanced grazing management will be indicated by a stable number of individuals. According to Achtziger et al. (2004) and Fischer et al. (2008), the presence of orchid populations indicates low-nutrient habitats, which are known to host a great variety of different species with similar site requirements.

The population trend of Tetrao urogallus shall be indicated by the number of displaying roosters. Due to the fact that capercaillies serve as umbrella species, a stable population indicates a rich habitat also suited for numerous other bird species (Borgo et al. 2009). The high sensitivity of these animals and the enormous efforts needed in surveying theme made the local hunting community the ideal partner for investigation. Data on capercaillies are regularly surveyed by the local hunting community by observing strict standards in sampling design. The additional benefit of this indicator is the integration of this relevant stakeholder group. Historically, the capercaillie has become the emblematic animal of the Carinthian part of the BR.

The amount of coarse woody debris in the forests of the BR is one of the most important ecological parameters. The indicator represents the attitude of land owners and forest managers towards a close-tonature forestry practice. It is assumed that a higher

Table 1 - Overview of indicators: Complete list showing all indicators, related data, survey interval, data source and reference data.

\begin{tabular}{|c|c|c|c|c|c|}
\hline $\mathrm{Nr}$ & Indicator & Related data & Survey interval & Source of data & Reference data \\
\hline \multicolumn{6}{|c|}{ Indicators displaying the social dimension } \\
\hline 1 & $\begin{array}{l}\text { Personal perception of the potential } \\
\text { for active participation in political and } \\
\text { social decision processes }\end{array}$ & $\begin{array}{l}\text { Mean value of the perception as a } \\
\text { number between } 1 \text { and } 10\end{array}$ & annual & questionnaire & - \\
\hline 2 & $\begin{array}{l}\text { Personal satisfaction with the Bio- } \\
\text { sphere Reserve (BR) }\end{array}$ & $\begin{array}{l}\text { Mean value of the perception as a } \\
\text { number between } 1 \text { and } 10\end{array}$ & annual & questionnaire & - \\
\hline 3 & Migration balance & $\begin{array}{l}\text { Ratio between in-migrating and } \\
\text { out-migrating people }\end{array}$ & annual & ÖSTAT & for reference region \\
\hline \multicolumn{6}{|c|}{ Indicators displaying the economic dimension } \\
\hline 4 & Development of the visitor tax in the BR & Amount of visitor tax in euros & annual & ÖSTAT & for reference region \\
\hline 5 & $\begin{array}{l}\text { Development of the local tax in the } \\
\text { four municipalities of the BR }\end{array}$ & $\begin{array}{l}\text { Amount of local tax in the four } \\
\text { municipalities of the BR in euros }\end{array}$ & annual & ÖSTAT & for reference region \\
\hline 6 & $\begin{array}{l}\text { Development of the agricultural land- } \\
\text { use forms in the BR }\end{array}$ & $\begin{array}{l}\text { - Number of agricultural holdings } \\
\text { - Total number of agricultural ar- } \\
\text { eas in use with and without Alpine } \\
\text { pastures } \\
\text { - Number of mowing areas on } \\
\text { steep slopes }\end{array}$ & annual & INVEKOS & for reference region \\
\hline \multicolumn{6}{|c|}{ Indicators displaying the ecologic dimension } \\
\hline 7 & $\begin{array}{l}\text { Population trend of Tetrao urogallus in } \\
\text { the BR }\end{array}$ & $\begin{array}{l}\text { Number of displaying roosters } \\
\text { found in the BR }\end{array}$ & $\begin{array}{l}\text { every second } \\
\text { year }\end{array}$ & $\begin{array}{l}\text { Field mapping } \\
\text { (by hunters) }\end{array}$ & - \\
\hline 8 & $\begin{array}{l}\text { Population trend of Nigritella rhellicani } \\
\text { in the BR }\end{array}$ & $\begin{array}{l}\text { Number of flowering Nigritella rhel- } \\
\text { licani found in ten observation plots }\end{array}$ & $\begin{array}{l}\text { every second } \\
\text { year }\end{array}$ & Field mapping & - \\
\hline 9 & $\begin{array}{l}\text { Development of the coarse woody } \\
\text { debris share in the forests }\end{array}$ & $\begin{array}{l}\text { Volume of coarse woody debris per } \\
\text { hectare of forest in sample plots }\end{array}$ & annual & ÖWl & for reference region \\
\hline \multicolumn{6}{|c|}{ Indicators displaying the management performance } \\
\hline 10 & \begin{tabular}{|l|} 
Development of visitor numbers \\
\end{tabular} & $\begin{array}{l}\text { Number of people participating in } \\
\text { events officially organized or certi- } \\
\text { fied by the BR management }\end{array}$ & annual & $\begin{array}{l}\text { Data collected } \\
\text { by the authors }\end{array}$ & - \\
\hline 11 & Development of media presence & $\begin{array}{l}\text { Number of press reports in print } \\
\text { media }\end{array}$ & annual & $\begin{array}{l}\text { Data collected } \\
\text { by the authors }\end{array}$ & - \\
\hline 12 & $\begin{array}{l}\text { Development of research activities } \\
\text { within the BR }\end{array}$ & $\begin{array}{l}\text { Number of research projects car- } \\
\text { ried out }\end{array}$ & annual & $\begin{array}{l}\text { Data collected } \\
\text { by the authors }\end{array}$ & - \\
\hline
\end{tabular}


amount of coarse woody debris increases the value of the forest for biodiversity conservation. The volume of coarse woody debris is surveyed regularly by the Austrian Forest Inventory by collecting data on a grid of sample plots.

Indicators representing the economic dimension:

The level of tourism levy in a region allows a reliable inference of any increasing added value of tourism and a lowered susceptibility towards external factors. Increased visitor taxes are closely related to increasing quality and rising price levels and therefore the positive development of the touristic sector.

In a similar way, increased revenues from local taxes indicate higher economic activity, which is directly related to more jobs and a higher added value. In the long term, a positive trend compared to communities outside the BR is intended.

Agriculture is one of the most important economic sectors in the BR region. Giuliani \& Flury (2009) underline the importance of agriculture as the basis for a multitude of value-added chains, especially in marginalized rural areas. The indicator is subdivided into four key figures, i.e. the number of agricultural holdings, the total amount of agricultural areas in use with and without alpine pastures, and the number of mowing areas on steep slopes. These four parameters are aggregated to a data cluster and have to be separately interpreted. In addition to its economic importance, the type and intensity of agricultural land-use is closely related to nature conservation issues (Holzner 2007; Anzengruber 2010).

Indicators representing the social dimension:

The social dimension is represented by the personal perception of the potential for active participation in political and social decision processes. This and the following indicator are being assessed by questionnaires (Figure 5), which are sent once a year to every household within the four communities in the BR. To promote participation in the survey, every returned questionnaire takes part in a lottery. The rewards range from regional products to touristic offers. A high degree of participation indicates the success of the BR in meeting one of its core principles: true bottom-up development and an active participation of all stakeholder groups in the ongoing management. These principles are rooted in the Seville Strategy of UNESCO's Biosphere Reserves (UNESCO 1996).

The personal satisfaction with the ongoing activities is a key benchmark for the acceptance of the BR. A positive attitude of the inhabitants, across all age groups and social strata, is considered a key factor for the long-term success. These data are also assessed by the questionnaire.

A positive migration balance points to a successful development of the peripheral region in terms of good infrastructure, job security and long-term per-

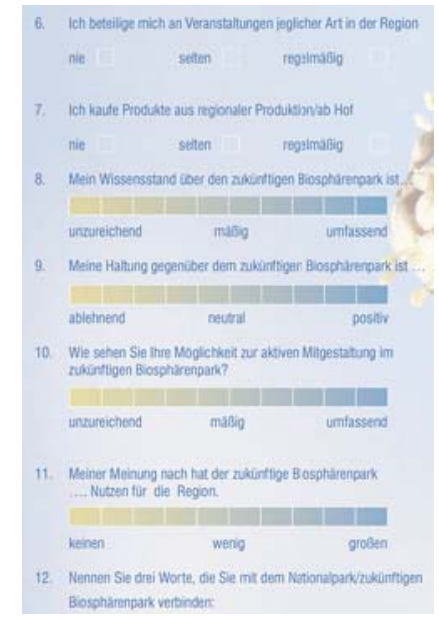

Figure 5 - Schematic diagram of the questionnaire for investigating regional perception, which has been sent to all registered households in all four communities of the Carinthian part of the BR. Figure created by the authors.

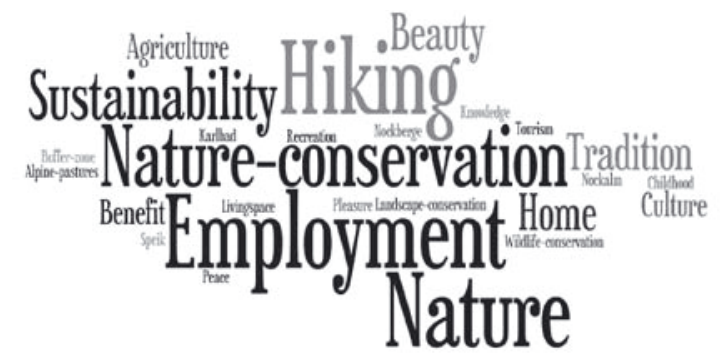

Figure 6-Spontaneous connotations with the BR. Word cloud created by an open-source online-tool by displaying the most frequent connotations with the BR. Source: www.wordle.net

spectives in cultural and social life. It is expected that the migration balance of the BR region (compared with the reference region) will significantly increase within the next decades.

\section{Indicators of management performance:}

The popularity of the visitor services shall be indicated by the number of people visiting events which are officially organized or certified by the BR management. With an increase in the quality and quantity of the services, the number of participants is supposed to increase. These events are very important for improving people's identification with the protected area.

Self-induced media presence is a very powerful tool for improving the good reputation of the protected area in public. Even if negative headlines are produced from time to time, they at least attest to a high public interest. Thus, the number of press reports in print media has been chosen as indicator for the success of public relation activities.

The number of research projects and scientific activities are a relevant indicator for UNESCO BRs. All research projects that have been either officially recognized, or at least co-financed or authorized by the park management are recorded. According to the Seville Strategy (UNESCO 1996) science and education are substantial pillars of BRs. 


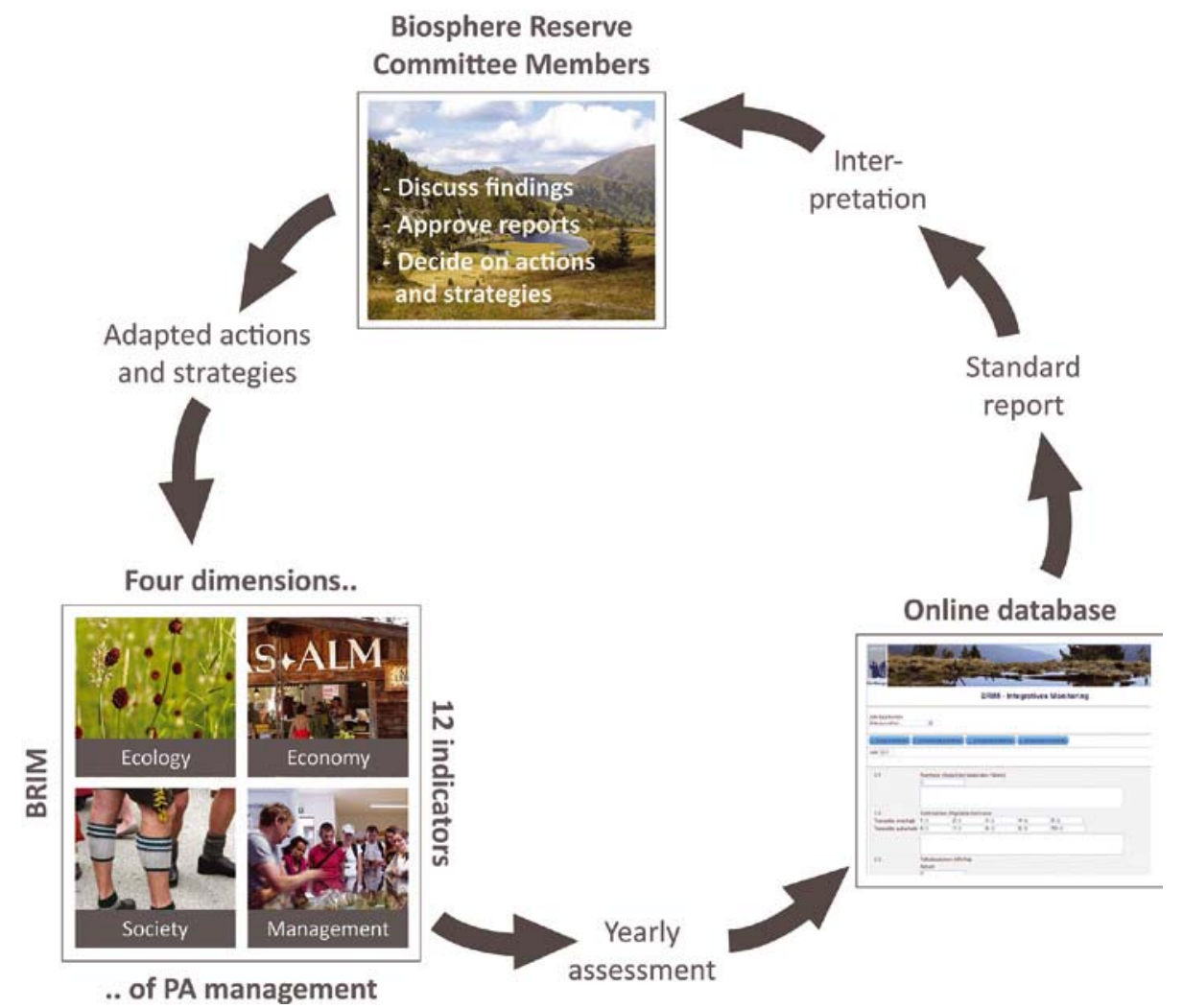

Figure 7 - Adaptive cycle of the BRIM Nockberge approach. Scheme showing the causal loop representing the integrated approach of the monitoring tool. Graphic design by the authors.

\section{Data management}

Choosing the right set of indicators is critical, but sound data management is equally important. Thus an online database has been customized to meet the criterion of comparability. The management has access to the input form as well as to the database which is the basis for any further interpretational work. The rigid input form requires a certain data format, a fact that enforces a consistent and sound data survey. In some cases data have to be pre-processed before being entered into the database. The indicator tourism levy, for example, requires a mean value of all four communities per capita. Once all annual data are fed into the database, the process of evaluation and interpretation will be carried out by an external institution and presented to the management. After reflecting on positive and negative trends, the actions and strategies may be adapted to improve performance. Figure 7 shows the causal loop representing the integrated approach of the monitoring tool.

\section{Test run}

Once the set of indicators and the facility for sound data management had been developed, a test-run of the monitoring was carried out to present first results before the BR was officially recognized by UNESCO in September 2012.

Data were collected for every indicator except for the ecological indicator Population trend of Tetrao urogallus. For the indicators Share of coarse woody debris, tourism levy, local tax, agricultural land-use forms, and migration balance, additional data were collected in the reference communities (Figure 8).

It became clear that the forests in the BR present a higher share of coarse woody debris than the reference forests. This had been expected as the area was a national park before being designated as BR. Nevertheless, more efforts will be needed in the future to ensure a natural development of the forest. The WWF, for example, recommends aiming for a volume of $30 \mathrm{~m}^{3}$ coarse woody debris per hectare by 2030 (Sauberer et al. 2007). With respect to the economic situation of the BR, the data reflect the weak economy in a peripheral rural area. Fewer full-time farmers remain in the BR communities, compared to the reference area. In addition, more people are leaving the area than moving into the $\mathrm{BR}$ region.

The results of the test-run constitute an essential baseline for the management. The subsequent annual monitoring will allow for tracking any change in the region since the launch of the BR. This information will be presented and discussed within the relevant stakeholder groups of the BR with a view to adapting the management measures if necessary. Significant trends are not expected to become visible for another five years.

\section{Concluding remarks}

Already UNESCO's 1995 Seville Strategy calls for extensive monitoring in BRs. However, the sites shall not only be used for making inventories on fauna and 
flora or recording meteorological data but also for collecting socio-economic data, reflecting the quality of life of its inhabitants and assessing the degree of sustainability of the regional development (Goal III, Objective 2). Although this request dates back almost 20 years, the implementation of an integrative monitoring scheme in practice remains difficult to this day. In recent years several attempts have been made to develop integrative monitoring schemes that reflect the performance of protected areas, such as BRs or national parks (e. g. ALPARC 2011; Fischer-Kowalski et al. 2008; Kowatsch et al. 2011; Stoll-Kleemann et al. 2011; Buer et al. 2013). The indicator sets developed for Alpine parks (ALPARC 2011: 25 indicators) and German protected areas (Kowatsch et al. 2011: 27 indicators) are currently being tested, but so far it cannot be assessed if they will be applicable and accepted in practice.

In Austria, Great Walsertal BR (designated in 2000) implemented a comprehensive socio-economic survey and acceptance study in 2005 (Coy \& Weixlbaumer 2006). However, so far there have not been sufficient resources available to carry out regular repeat surveys. To date, Wienerwald BR (designated in 2005) only implements ecological monitoring schemes, such as forest inventories in core areas and soil assessments.

It can therefore be assumed that at present the indicator set established for the Carinthian part of the BR Salzburger Lungau and Kärntner Nockberge is the most functional monitoring scheme for BRs in Austria. It covers the different functions, is slim enough to be repeated annually and has been accepted in the region during an intensive participative process. However, the monitoring scheme will have to be applied for several years before it can be assessed if it really succeeds in displaying the relevant ecological and socio-economic trends in the BR region and proves to be an appropriate tool for adaptive management. The concept of screen shots described above allows covering changing issues once the management plan has been agreed on. Additional efforts may be necessary if more comprehensive acceptance surveys are to be carried out. The experiences of Great Walsertal BR may be useful in this respect.

\section{Acknowledgements}

The study received substantial support from the Austrian MAB Committee at the Austrian Academy of the Sciences. The authors want to thank the committee not only for funding but also for very helpful comments, in particular from Günter Köck, Marina Fischer-Kowalski, Georg Grabherr and Arne Arnberger. In the Nockberge region the project was initiated and supported by Dietmar Rossmann and Heinz Maier, but also by members of the former National Park Committee. Last but not least, we thank Karin Grasnick for substantial input on social indicators.
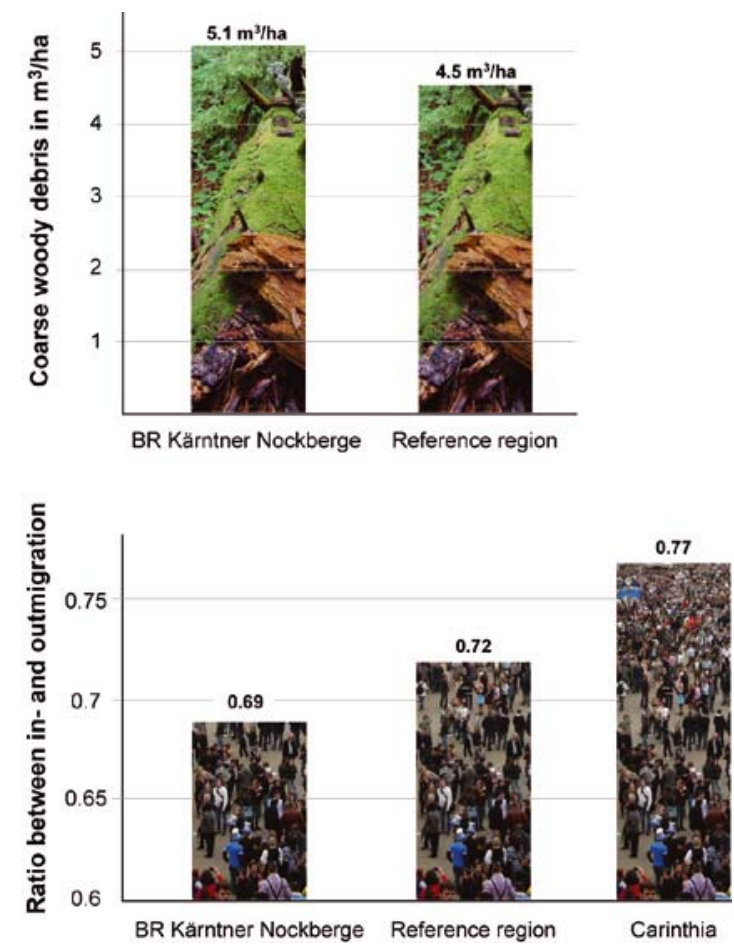

Figure 8-Two figures showing sample results from the first test run. Graphics created by the authors.

\section{References}

Achtziger, R., H. Stickroth \& R. Zieschank 2004. Nachhaltigkeitsindikator für die Artenvielfalt. Ein Indikator für den Zustand von Natur \& Landschaft in Deutschland. Angewandte Landschaftsökologie 63. Bundesamt für Naturschutz, Bonn - Bad Godesberg.

ALPARC 2011. Katalog der Indikatoren zur Messung der Effektivität von Managementmaßnahmen. CIME_1. 1. Fassung. Im Auftrag des schweizerischen Bundesamtes für Umwelt (BAFU).

Anzengruber, M. 2010. Almwirtschaft im Bundesland Salzburg. Eine Analyse agrarpolitischer Maßnahmen und deren Auswirkungen auf die Almlandschaft mit besonderer Berücksichtigung der Nördlichen Kalkalpen, Salzburg. Landschaft und Nachbaltige Entwicklung 3.

Borgo, A., M. Cassol, S. Mattedi, M. Favalli, F. Genero \& Fintel Engineering srl. 2009. Entwicklung von gemeinsamen Konzepten für das Monitoring in Natura 2000 Schutzgebieten. Biodiversitäts-Indikatoren, Sozioökonomische Indikatoren und Monitoring-Protokolle für SCI/SPA in den Ostalpen.

Buer, C., F. Solbrig \& S. Stoll-Kleemann (eds.) 2013. Sozioökonomisches Monitoring in deutschen UNESCO-Biosphärenreservaten und anderen Großschutzgebieten. BfN-Skripten 329.

Coy, M. \& N. Weixlbaumer 2006. Zukünftige Entwicklungsstrategien für den Biosphärenpark Großes Walsertal. Eine regionalwirtschaftliche und perzeptionsgeographische Analyse. Projektendbericht, Österreichische Akademie der Wissenschaften, Wien.

Ellmauer, T. (ed.) 2005. Entwicklung von Kriterien, Indikatoren und Schwellenwerten zur Beurteilung des Erhal- 
tungszustandes der Natura 2000-Schutzgüter. Band 1: Vogelarten des Anhangs I der Vogelschutz-Richtlinie. Im Auftrag der neun österreichischen Bundesländer, des Bundesministerium für Land- und Forstwirtschaft, Umwelt und Wasserwirtschaft \& der Umweltbundesamt $\mathrm{GmbH}$.

Fancy, S.G., J.E. Gross \& S.L. Carter 2009. Monitoring the condition of natural resources in US National Parks. Environmental Monitoring and Assessment 151: 161-174.

Fischer, M., W. Adler \& K. Oswald 2008. Exkursionsflora von Österreich, Liechtenstein und Südtirol. 3. verbesserte Auflage.

Fischer-Kowalski, M., K.-H. Erb \& S.J. Singh 2008. Extending BRIM to BRIA: Social monitoring and integrated sustainability assessment. In: Lee, C. \& T. Schaaf (eds.), Proceedings of the $1^{\text {st }}$ International Thematic Workshop held in Vienna, Austria 9-11 May 2004, Global Environmental Social Monitoring. 138-148.

Giuliani, G. \& C. Flury 2009. Regionalwirtschaftlicher Beitrag der Landwirtschaft in benachteiligten Regionen der Schweiz:

Goldsmith, B. 1991. Monitoring for Conservation and Ecology. London.

Heinze, B. 2004. Forschung und Monitoring in deutschen Biosphärenreservaten: Ein Überblick. In: Deutsches MAB-Nationalkomitee (Hrsg.), Voller Leben. 220-224.

Holzner, W., D. Bogner, T. Geburek, M. Tiefenbach \& S. Zech 2006. MOBI-e - Entwicklung eines Konzeptes für ein Biodiversitäts-Monitoring in Österreich.

Jungmeier, M., I. Paul-Horn, D. Zollner, F. Borsdorf, S. Lange, B. Reutz-Hornsteiner, K. Grasenick, D. Rossmann, R. Moser \& C. Diry 2009. Part_b: Partizipationsprozesse in Biosphärenparks - Interventionstheorie, Strategieanalyse und Prozessethik am Beispiel vom Biosphärenpark Wienerwald, Großes Walsertal und Nationalpark Nockberge - Band I: Zentrale Ergebnisse. Studie im Auftrag von: Österreichisches MAB-Nationalkomitee, Österreichische Akademie der Wissenschaften, Klagenfurt.

Kowatsch, A., U. Hampicke, L Kruse-Graumann \& H. Plachter 2011. Indikatoren für ein integratives Monitoring in deutschen Großschutzgebieten. Endbericht des gleichnamigen $\mathrm{F}+\mathrm{E}-$ Vorhabens. Bf $\mathrm{N}$ Skripten 302.

Kupper, P. 2012. Wildnis schaffen. Eine transnationale Geschichte des Schweizerischen Nationalparks. Nationalpark-Forschung 97.

Lange, S. 2005. Leben in Vielfalt. UNESCO-Biosphärenreservate als Modellregionen für ein Miteinander von Mensch und Natur. Wien.

Nolte, C., F. Leverington, A. Kettner, M. Marr, G. Nielsen, B. Bomhard, S. Stolton, S. Stoll-Kleemann \& M. Hockings 2010. Protected Area Management Effectiveness Assessments in Europe - A review of application, methods and results. BfN-Skripten 271a.

Sauberer, N., N. Milasowszky \& L. Sachslehner 2007. Nachbaltiges Waldbiomassenmanagement im Biosphärenpark Wienerwald.
UNESCO (ed.) 1996. Biosphärenparke. Die SevillaStrategie und die Internationalen Leitlinien für das Weltnetr: Bundesamt für Naturschutz, Bonn.

Stoll-Kleemann, S., C. Buer \& F. Solbrig 2012. Erprobung eines sozioökonomischen Monitoringsystems in ausgewählten deutschen Großschutzgebieten, In: Brickwedde, F., R. Stock \& W. Wahmhoff (Hsg.), Das Nationale Naturerbe in der Praxis - Impulse, Herausforderungen, Perspektiven. 17. Internationale Sommerakademie St. Marienthal. Initiativen zum Umweltschutr: 85. Berlin. 325-332.

Stoll-Kleemann, S., C. Buer \& F. Solbrig 2011. Socio-economic monitoring in protected areas in Germany - what do local people and their mayors think about their biosphere reserve? In: Wesemüller, H., N. Kuschniok, J. Schünemann \& V. Kreft (eds.), Progress Report 2009-2011. National Nature Landscapes. EUROPARC Germany. 30-33.

\section{Authors}

Michael Jungmeier (corresponding author)

The biologist and human geographer runs the MSc Programme Management of Protected Areas at the Department of Geography and Regional Studies at the University of Klagenfurt. He is CEO of E.C.O. Institute for Ecology in Klagenfurt, Austria, a consultancy specializing in protected areas. Contact: jungmeier@e-c-o.at.

\section{Tobias Köstl}

holds a degree in Natural Resources and Protected Area Management. He works for E.C.O. Institute for Ecology in Klagenfurt, Austria, as project manager in the field of applied ecology and research. Contact: koestl@e-c-o.at

\section{Sigrun Lange}

CEO of E.C.O. Germany in Munich, Germany. She holds a diploma in Biology and a Master degree in Protected Areas Management. Since 2003 she has focused particularly on the implementation of UNESCO's MAB Programme and contributed to the development of the national criteria for Austrian Biosphere Reserves in 2005. Contact: lange@e-c-odeutschland.de

\section{Markus Bliem}

Managing Director of the Institute for Advanced Studies Carinthia. His areas of research include Energy and Environmental Economics, with particular reference to environmental valuation of non-market goods and services. He holds a Master degree in Environmental Systems Sciences from the University of Graz and a PhD in Economics from the University of Klagenfurt. Contact: bliem@carinthia.ihs.ac.at 